Ive Marx, Gerlinde Verbist

\title{
Belgium, a poster child for inclusive growth?
}

\section{WORKING PAPER}

No. 18.10

May 2018

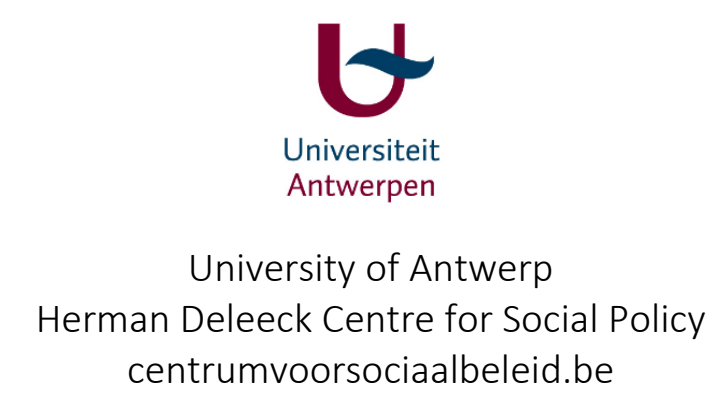


Belgium, a poster child for inclusive growth?

Ive Marx \& Gerlinde Verbist

Working Paper No. 18/09

May 2018

Forthcoming in Brian Nolan (ed.), Inequality and Inclusive Growth in Rich Countries

Shared Challenges and Contrasting Fortunes, Oxford: Oxford University Press, 2018 


\section{Introduction}

Belgium's middle income households have enjoyed rising real living standards in an almost uninterrupted way for as long as household income data goes back, which is some thirty years. Even the recent economic crisis did little to slow the unglamorous but steady rises households experienced up to that point, making Belgium something of an exception in the rich world.

Belgium's remarkably resilience during the crisis period finally earned it attention and even a measure of admiration among some international commentators. Often seen as a prime case of unadaptive immobility in a rapidly evolving world, Belgium started to draw international attention during the crisis precisely because of its 'successful' inertia, even when other countries were turning to drastic measures in times of exceptional adversity. In an article published in 2011 in the London Review of Books, John Lanchester wrote: "Oh strangest of all strangenesses, the deep longing for the whole world to be more like Belgium." Using perhaps less memorable phrases, Paul Krugman wrote columns around the same time espousing 'the secret of Belgium's success"

In the eyes of both commentators, that secret essentially boiled down to the fact that during one of severest crises in recent memory, Belgium was without a government for more than 15 months, establishing a world record for the longest cabinet formation in modern political history. That absence had meant no cuts and no 'austerity' packages, contrary to what was considered de rigueur around that time. In fact, and as we will argue here, the story is more complicated and perhaps therefore also more interesting.

Belgium's atypical and fascinating trajectory extends far beyond the crisis period, as this chapter will bring out. Belgium stands out in that there has been less of a divergence than in many places elsewhere between the conventional measures of economic affluence, like GDP per capita, and actual household living standards as recorded through surveys and other microdata. In other words, the benefits to economic growth appear to have been more equitably spread than in many other rich economies, where the rich have tended to gain disproportionately. 
One plausible reason for Belgium's resilience not only during the crisis period but over the longer time span covered in this chapter lies, we contend, in its social corporatist model. Belgium's multi-level political governance still firmly embeds trade unions and employers' organizations - the social partners- in the institutional framework. Social partners wield significant influence in social and economic policy and hold direct control over wage setting. Trade union membership remains relatively high and has not declined over recent decades, in marked contrast to trends in neighbouring countries. While union membership rates are often interpreted as a manifestation of "working class" political power, trade union membership rates in Belgium are actually highest among those in the middle income classes (Kuypers and Marx, 2016). Likewise, small and middle sized companies, which are economically more significant than big companies, are numerically relatively important in the membership of employer's organisations. As a consequence middle class ${ }^{1}$ interests - on the one end represented by the unions, at the other by the employers' organisations - play a key if not dominant role in collective bargaining and in social concertation in general.

In this chapter we present what we hope are plausible arguments for why we think that social corporatism - particularly comprehensive collective bargaining - has contributed to a more equitable distribution of economic growth than seen in many other countries. That is not to say that we claim to present definitive evidence of this here. That would of course require a different research design than a one country case study.

We also argue that another factor contributing to middle class stability has been Belgium's welfare state and the public sector in general. Belgium has one of the highest levels of public spending in the rich world, with tax levels to match. These tax levels are a continuing source of dissatisfaction and political debate, yet many of the benefits flow directly back to the middle classes paying these taxes, as we will show. This is also the case for such provisions as health, education or child care, all of which impose much higher burdens on middle class budgets in many other countries.

\footnotetext{
${ }^{1}$ Note that in this chapter we will use the terms 'middle class' and 'middle income' interchangeably. What are generally thought of as "middle class" people in a sociological way - people who are 'middle class' by educational background, occupation and self-identification - are often in very diverse positions in the income spectrum. A teacher who is a lone parent will generally have a much lower living standard than a colleague married to another teacher. Professionals like doctors or teachers who are generally thought of as middle class are often in the very upper ranges of the income distribution, especially if their partners have similar occupations.
} 
That is not to say that Belgium deserves to become the poster child for more inclusive growth elsewhere in the rich world. For middle class living standards are not within reach of important sections of the population. The prospects for people with few skills and especially people with a migration background of joining middle class ranks are dismal. And for a country with a high living standard, a low level of income inequality and a high level of social spending, Belgium has a remarkably high share of the population living in relative poverty, taking much of the gloss away from Belgium as a model for inclusive growth.

In what follows we start by looking at middle income living standards in some detail, decomposing these to gauge the relative importance of employment and earnings trends as well as welfare state benefits. Subsequent sections add further context to these numbers. In the next-to-final section we ask whether Belgium offers a model, if only in parts, for inclusive growth that might deserve emulation elsewhere. We also question whether the income based measures of well-being on which we mostly concentrate in this chapter capture the whole middle-class experience. The final section considers the prospects for Belgium's middle class.

\section{A thriving middle class}

As Nolan et al. (2016) have shown, per capita GDP has in many countries risen faster than actual real household incomes, especially for those around the median and below. The size of that divergence varies very substantially, with the US a very clear outlier. Belgium lies at the other end of the spectrum. It is one of the countries where actual household living standards have tracked GDP growth most closely, both having increased substantially. In addition, while the share of national income represented by wages, salaries and benefits - the labour share has declined in nearly all OECD countries, this trend too has been far less obvious in Belgium (OECD, 2012)

Figure 1: Evolution of equivalent disposable household income (median and Q3 average) and GDP per capita (2011=100), 1985-2015 


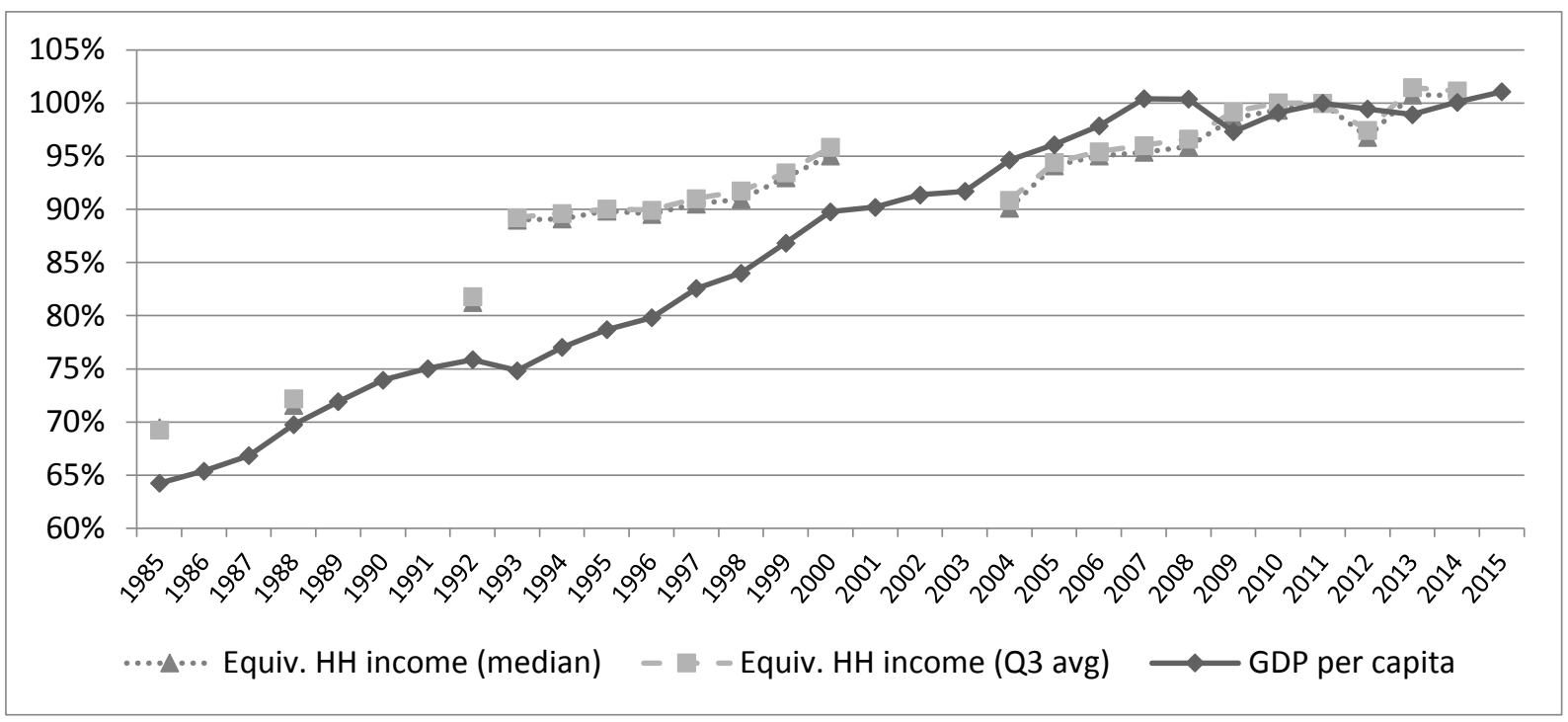

Source: GDP per capita-OECD data; Equivalent household income: own calculations on household income survey data (SEP for 1985-1992; ECHP for 1993-2000; EU-SILC for 2004-2014).

Figures 1 and 2 shows the annualized growth rates of real equivalent disposable household income by income quintile for the period 1985 until $2014^{2}$. Unfortunately, there is no entirely consistent time series data available for the whole period but the respective surveys used in this graph are of good quality, comparable in coverage, and the income concepts used are also sufficiently similar ${ }^{3}$. We distinguish four periods, notably 1985-1992 using data from the Socio-Economic Panel (SEP) ${ }^{4}$; 1993-2000 using data from the European Community Household Panel (ECHP); the pre-crisis period 2004-2008 using data from EU Statistics of Income and Living Conditions (SILC) and the post crisis period 2008-2014 also using SILC data. We use averages per quintile because these are more easily decomposed, as we will do in this paper. Moreover, as Figure 1 shows, the evolution of average income in the third income quintile is almost identical to that of median incomes.

Figure 2 shows relatively mild but steady increases across the income spectrum. The line for the whole time period (1985-2014) represents a weighted average of the annual growth rates

\footnotetext{
${ }^{2}$ We are very grateful to Jeroen Horemans for his invaluable support for the calculations.

${ }^{3}$ The major difference being that SEP captured monthly net household incomes while the other surveys cover yearly incomes. However, in terms of the income components covered there is a high degree of similarity.

${ }^{4}$ SEP has four waves, notably 1985, 1988, 1992 and 1997. We only use the first three, as the period 1993-1997 is covered by the ECHP data.
} 
for the periods for which we have consistent data. This shows slightly higher growth in the bottom quintile than in the next four quintiles, where growth was near identical.

There were periods that living standards increased more for lower income households, as during the period 1993-2000. The pre-crisis period covered by EU-SILC (2003-2008) was a period of relatively strong increases, especially for the bottom and the top quintiles. Living standards growth has been far weaker after 2003 with even a slight drop for higher income households. It is worth adding here that the averages in the outer quintiles are potentially more sensitive for what happens at the very bottom and the very top of the distribution respectively ${ }^{5}$. Our main focus is on the middle quintiles and there the picture is very flat.

This broad picture of relatively equitably shared growth between 1985 and 2014 is also roughly consistent with the picture of stable overall income inequality, as captured by the (middle income sensitive) GINI coefficient, shown in chapter 2 and in other comparative studies of inequality (e.g. OECD, 2008; OECD, 2011, Nolan et al. 2014)

Figure 2: Annual growth rate of real equivalent disposable household income by quintile, overall population, Belgium 1985-2014

\footnotetext{
${ }^{5}$ In an earlier exercise (not shown here) where we looked at trends for various cut-off points in the percentile distribution the picture is more steady. 


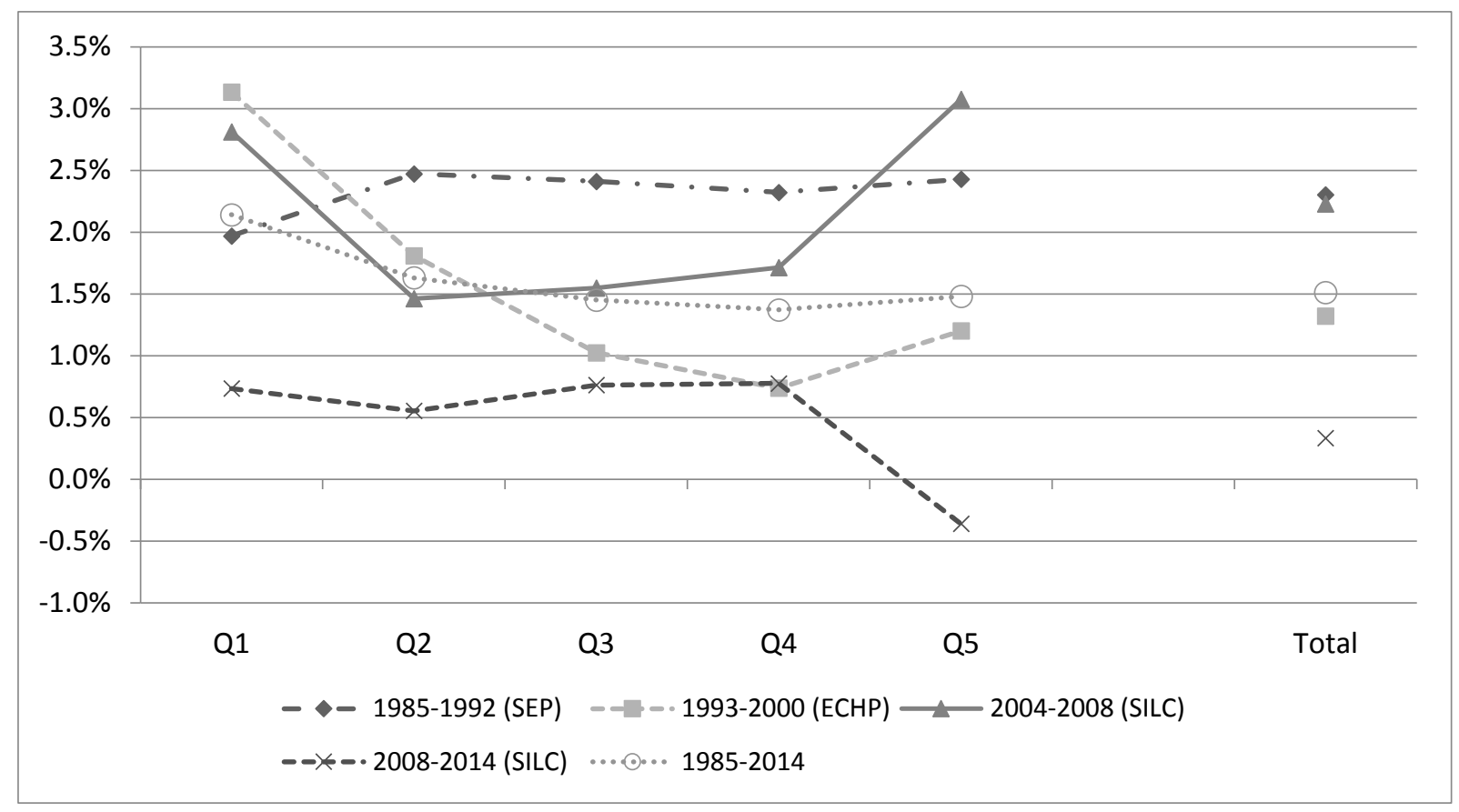

Note: The average growth rate for 1985-2014 is calculated as the weighted average of the annual growth rates of the different sub-periods.

Source: own calculations on SEP, ECHP and SILC.

Let us look at a number of important drivers behind these trends. We focus our commentary on the working age population (18 to 65 years) but as Table 1 shows, trends for the overall and the working age population have been very similar. 
Table 1: Annual growth rate of real equivalent household disposable income, earnings and benefits by quintile, Belgium 1985-2014.

\begin{tabular}{|c|c|c|c|c|c|c|}
\hline \multirow[b]{2}{*}{ Period } & & \multicolumn{3}{|c|}{ Disposable household income } & \multirow{2}{*}{$\begin{array}{c}\text { Earnings } \\
\text { Total population }\end{array}$} & \multirow{2}{*}{$\begin{array}{c}\text { Benefits } \\
\text { Total population }\end{array}$} \\
\hline & & Total population & Elderly & Working age & & \\
\hline \multirow[t]{6}{*}{ 1985-1992 (SEP) } & Q1 & $1.97 \%$ & $2.34 \%$ & $1.97 \%$ & $-0.97 \%$ & $3.23 \%$ \\
\hline & Q2 & $2.47 \%$ & $2.55 \%$ & $2.46 \%$ & $2.76 \%$ & $1.32 \%$ \\
\hline & Q3 & $2.41 \%$ & $2.56 \%$ & $2.41 \%$ & $3.06 \%$ & $0.45 \%$ \\
\hline & Q4 & $2.32 \%$ & $2.33 \%$ & $2.34 \%$ & $2.39 \%$ & $1.22 \%$ \\
\hline & Q5 & $2.43 \%$ & $3.07 \%$ & $2.40 \%$ & $1.89 \%$ & $1.75 \%$ \\
\hline & Total & $2.30 \%$ & $2.11 \%$ & $2.38 \%$ & $2.08 \%$ & $1.65 \%$ \\
\hline \multirow[t]{6}{*}{ 1993-2000 (ECHP) } & Q1 & $3.13 \%$ & $3.16 \%$ & $3.11 \%$ & $1.87 \%$ & $4.22 \%$ \\
\hline & Q2 & $1.81 \%$ & $1.92 \%$ & $1.70 \%$ & $1.69 \%$ & $0.59 \%$ \\
\hline & Q3 & $1.03 \%$ & $1.15 \%$ & $0.97 \%$ & $1.49 \%$ & $-0.17 \%$ \\
\hline & Q4 & $0.74 \%$ & $0.66 \%$ & $0.79 \%$ & $1.14 \%$ & $-1.17 \%$ \\
\hline & Q5 & $1.20 \%$ & $1.71 \%$ & $1.01 \%$ & $2.89 \%$ & $-6.23 \%$ \\
\hline & Total & $1.32 \%$ & $1.39 \%$ & $1.37 \%$ & $2.01 \%$ & $-0.77 \%$ \\
\hline \multirow[t]{6}{*}{$2004-2008$ (SILC) } & Q1 & $2.81 \%$ & $3.04 \%$ & $2.94 \%$ & $2.78 \%$ & $3.23 \%$ \\
\hline & Q2 & $1.46 \%$ & $1.22 \%$ & $1.58 \%$ & $2.76 \%$ & $0.20 \%$ \\
\hline & Q3 & $1.55 \%$ & $1.75 \%$ & $1.44 \%$ & $2.25 \%$ & $0.09 \%$ \\
\hline & Q4 & $1.71 \%$ & $1.66 \%$ & $1.67 \%$ & $1.33 \%$ & $2.55 \%$ \\
\hline & Q5 & $3.08 \%$ & $1.55 \%$ & $2.97 \%$ & $2.35 \%$ & $3.16 \%$ \\
\hline & Total & $2.23 \%$ & $1.21 \%$ & $2.27 \%$ & $2.13 \%$ & $1.65 \%$ \\
\hline \multirow[t]{6}{*}{ 2008-2014 (SILC) } & Q1 & $0.74 \%$ & $0.35 \%$ & $0.67 \%$ & $-0.34 \%$ & $0.35 \%$ \\
\hline & Q2 & $0.55 \%$ & $0.70 \%$ & $0.54 \%$ & $-1.34 \%$ & $2.11 \%$ \\
\hline & Q3 & $0.76 \%$ & $0.72 \%$ & $0.81 \%$ & $0.25 \%$ & $1.52 \%$ \\
\hline & Q4 & $0.78 \%$ & $0.92 \%$ & $0.80 \%$ & $0.62 \%$ & $0.87 \%$ \\
\hline & Q5 & $-0.36 \%$ & $0.32 \%$ & $-0.33 \%$ & $-0.43 \%$ & $0.07 \%$ \\
\hline & Total & $0.33 \%$ & $2.59 \%$ & $0.22 \%$ & $-0.12 \%$ & $1.09 \%$ \\
\hline
\end{tabular}

Note: Household income and its two components have been equivalised using the modified OECD scale. Elderly are those individuals aged above 65, while working age are those aged between 18 and 64. Quintiles are constructed on the basis of equivalent disposable income over the total population.

Source: own calculations on SEP, ECHP and SILC. 
Earnings have been an important driver of income growth, and as Table 1 shows, in most periods covered here household earnings increased relatively evenly across the income distribution. Benefits increased less than earnings in the first two periods but they were clearly pro-poor, i.e. there were stronger increases for the bottom quintile than for the other quintiles. In the last two periods household benefits increases were more significant but they were also more evenly spread. 
Table 2: Annual growth rate of real individual earnings and share of earners by quintile, Belgium 1985-2014.

\begin{tabular}{|c|c|c|c|c|c|c|c|c|}
\hline \multirow[b]{2}{*}{ Period } & & \multirow{2}{*}{$\begin{array}{c}\text { Total } \\
\text { earnings }\end{array}$} & \multicolumn{3}{|c|}{ Average earnings } & \multicolumn{3}{|c|}{ Share of earners } \\
\hline & & & Total & Men & Women & Total & Men & Women \\
\hline \multirow[t]{6}{*}{ 1985-1992 (SEP) } & Q1 & $-0.32 \%$ & $0.98 \%$ & $1.61 \%$ & $0.25 \%$ & $-1.29 \%$ & $-2.23 \%$ & $2.63 \%$ \\
\hline & Q2 & $2.75 \%$ & $-0.04 \%$ & $0.54 \%$ & $2.21 \%$ & $2.79 \%$ & $0.25 \%$ & $10.49 \%$ \\
\hline & Q3 & $3.32 \%$ & $0.27 \%$ & $0.54 \%$ & $1.58 \%$ & $3.04 \%$ & $0.96 \%$ & $6.81 \%$ \\
\hline & Q4 & $2.35 \%$ & $1.10 \%$ & $1.30 \%$ & $1.22 \%$ & $1.23 \%$ & $0.39 \%$ & $2.40 \%$ \\
\hline & Q5 & $1.68 \%$ & $1.21 \%$ & $1.14 \%$ & $1.45 \%$ & $0.46 \%$ & $0.06 \%$ & $0.95 \%$ \\
\hline & Total & $2.18 \%$ & $0.80 \%$ & $1.11 \%$ & $0.94 \%$ & $1.37 \%$ & $0.18 \%$ & $3.39 \%$ \\
\hline \multirow[t]{6}{*}{$1993-2000$ (ECHP) } & Q1 & $3.06 \%$ & $1.26 \%$ & $2.52 \%$ & $0.24 \%$ & $1.78 \%$ & $2.22 \%$ & $2.27 \%$ \\
\hline & Q2 & $2.08 \%$ & $-0.41 \%$ & $0.87 \%$ & $-1.28 \%$ & $2.50 \%$ & $0.52 \%$ & $5.13 \%$ \\
\hline & Q3 & $2.03 \%$ & $-0.13 \%$ & $-0.22 \%$ & $0.75 \%$ & $2.15 \%$ & $1.29 \%$ & $3.44 \%$ \\
\hline & Q4 & $0.69 \%$ & $0.52 \%$ & $0.42 \%$ & $0.85 \%$ & $0.16 \%$ & $-0.89 \%$ & $1.38 \%$ \\
\hline & Q5 & $1.03 \%$ & $0.01 \%$ & $0.72 \%$ & $-0.85 \%$ & $1.01 \%$ & $0.82 \%$ & $1.35 \%$ \\
\hline & Total & $1.58 \%$ & $0.12 \%$ & $0.61 \%$ & $-0.22 \%$ & $1.46 \%$ & $0.81 \%$ & $2.40 \%$ \\
\hline \multirow[t]{6}{*}{ 2004-2008 (SILC) } & Q1 & $0.78 \%$ & $-3.32 \%$ & $-2.01 \%$ & $-4.53 \%$ & $4.24 \%$ & $2.5 \%$ & $7.06 \%$ \\
\hline & Q2 & $1.40 \%$ & $-1.64 \%$ & $-2.03 \%$ & $-0.46 \%$ & $3.09 \%$ & $1.21 \%$ & $5.25 \%$ \\
\hline & Q3 & $1.71 \%$ & $-0.19 \%$ & $-0.15 \%$ & $0.31 \%$ & $1.90 \%$ & $0.80 \%$ & $3.31 \%$ \\
\hline & Q4 & $1.40 \%$ & $0.56 \%$ & $0.60 \%$ & $0.60 \%$ & $0.83 \%$ & $0.60 \%$ & $1.13 \%$ \\
\hline & Q5 & $1.96 \%$ & $0.97 \%$ & $1.38 \%$ & $0.46 \%$ & $0.98 \%$ & $0.77 \%$ & $1.24 \%$ \\
\hline & Total & $1.70 \%$ & $0.02 \%$ & $-0.13 \%$ & $-0.39 \%$ & $1.69 \%$ & $0.97 \%$ & $2.59 \%$ \\
\hline \multirow[t]{6}{*}{ 2008-2014 (SILC) } & Q1 & $-1.48 \%$ & $0.62 \%$ & $-0.17 \%$ & $2.30 \%$ & $-2.09 \%$ & $-3.91 \%$ & $-0.20 \%$ \\
\hline & Q2 & $-0.10 \%$ & $0.49 \%$ & $0.62 \%$ & $1.04 \%$ & $-0.59 \%$ & $-2.15 \%$ & $1.30 \%$ \\
\hline & Q3 & $1.13 \%$ & $0.54 \%$ & $-0.35 \%$ & $1.86 \%$ & $0.59 \%$ & $0.78 \%$ & $0.37 \%$ \\
\hline & Q4 & $0.62 \%$ & $0.25 \%$ & $-0.20 \%$ & $1.12 \%$ & $0.37 \%$ & $0.22 \%$ & $0.59 \%$ \\
\hline & Q5 & $-0.38 \%$ & $-0.39 \%$ & $-0.67 \%$ & $0.10 \%$ & $0.00 \%$ & $-0.16 \%$ & $0.20 \%$ \\
\hline & Total & $0.02 \%$ & $0.12 \%$ & $-0.23 \%$ & $1.11 \%$ & $-0.10 \%$ & $-0.53 \%$ & $0.42 \%$ \\
\hline
\end{tabular}

Note: Earnings include both wages and income from self-employment; since 2007 it also includes the benefit earners derive from a company car. Average earnings are averaged over those with strictly positive earnings. Quintiles are constructed on the basis of equivalent disposable income over the total population.

Source: own calculations on SEP, ECHP and SILC. 
We now investigate the drivers of household earnings in a bit more detail, by looking at earnings at the individual level. As Table 2 shows, the total mass of earnings increased steadily until the crisis of 2008. In the period 1985-1992 the increase was strongest in the middle of the income distribution, while in the nineties the middle and lower groups saw the strongest increase. In the years prior to the crisis, growth shifted more towards the middle and the top of the distribution. After 2008 earnings among the bottom and the top groups decreased, while the middle quintile saw an increase.

The major driver behind the trend in overall earnings is the share of earners, and especially the share of female earners. Until 2008 the share of female earners increased considerably with annual growth rates ranging from 2.4\% (1993-2000) to 3.4\% (1985-1992). These increases mainly took place in the lower middle of the household income distribution (e.g. an average annual growth of 5\% to $10 \%$ in Q2, and 3\% to $7 \%$ in Q3 in those three periods). The share of male earners has been more stable overall. A different pattern emerges when we look at average earnings of earners: in general (and especially at the bottom of the distribution) men have experienced a higher growth rate than women. However, in the middle of the distribution average earnings of women grew faster than men's earnings.

\section{Employment trends}

In the next sections we add context to these trends. Labour remains the main source of income of working age households and so we start by looking at employment and earnings trends in somewhat more detail. 
Figure 3: Labour force participation rates by sex and age, Belgium 1983-2014

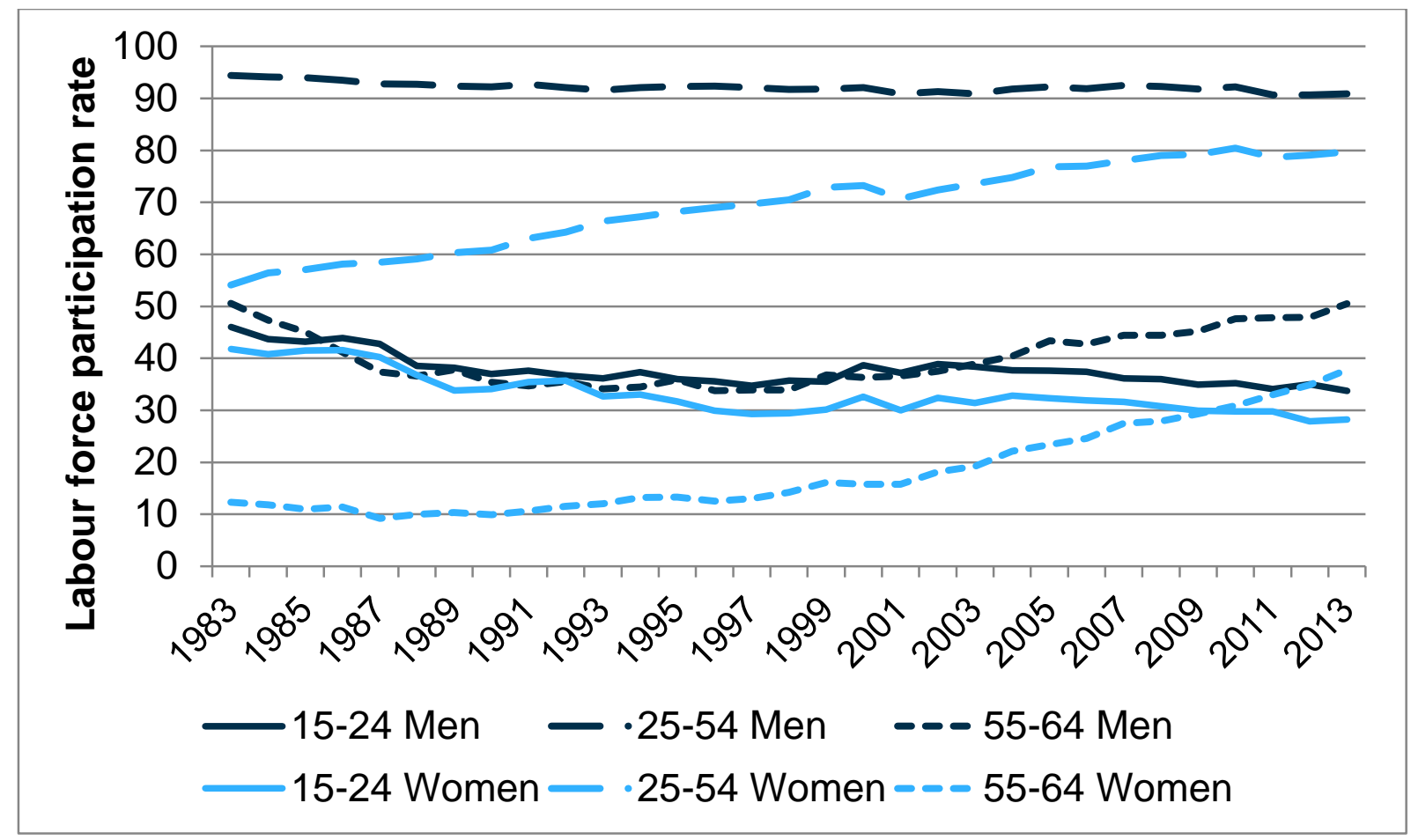

Source: OECD based on LFS.

As this volume brings out, employment growth - particularly the rise of double earnership among couples of working age - has been an important driver of rising middle class living standards in many countries, or an important compensating mechanism in countries with weak or negative real wage growth around the middle.

Employment growth in Belgium has been relatively weak compared to other northern European countries. Employment rates for the working age population have risen modestly, with particularly strong rises from the mid-1990s until the late 2000s. As Figure 3 shows, the broad picture is that prime-age male employment has remained steady at a high level. Fewer young adult men work, mainly as a consequence of extended education careers, and for older workers the pattern is U-shaped. Much stronger trends are to be seen for women: employment among prime-aged and, more recently, pre-retirement age women has increased strongly.

One important contextual element here is that Belgium's economy underwent major restructuring over the past decades. An early industrialiser, Belgium recorded among the 
largest relative job losses in manufacturing industry in the OECD area during the 1970s and 1980s, mainly because of major structural adjustments in steel, coal and textile industries. The collapse in the demand for labour occurred precisely at a time when many youngsters (the sizable post war baby boom cohort) and women were entering the labour market. Faced with a sudden and massive unbalance between labour demand and supply, Belgium resorted to an expansion of early retirement routes in order to drain off excess labour supply and to alleviate the social consequences of structural economic adjustment, especially massive job shedding in industry.

It has proved very difficult to scale back the early retirement schemes instituted to absorb the consequences of economic restructuring. This accounts for Belgium's exceptionally low employment rate among those between the age of 55 and 64 . Once in place a powerful coalition emerged around the main early retirement scheme. Employers liked it because it offered a cheap and low-resistance way for companies to make less productive workers redundant. And once in place, many workers came to expect to get what many of their former co-workers had got: the chance to leave the labour market early with an attractive financial package. Successive attempts to scale back early retirement and to increase the effective age of retirement have encountered enormous resistance from the trade-unions, and this continues until this day. Employers have been more consistent in their demands for scaling back the system yet that has not restrained them from keenly using early retirement provisions for restructuring.

Mass early retirement has allowed Belgium to pursue a high productivity path. In addition, steady wage increases resulting from automatic indexation of wages together with multi-level collective bargaining (see below) have spurred continuous investments in labour-saving automation and innovation. The result is that Belgium has among the highest productivity levels in the world if measured by output per hour worked. That means that productivity requirements are high causing employment rates for people over the age of 55 to remain exceptionally low. A further factor here is that wage rules as contained in collective agreements cause wages to rise steeply with age and seniority.

The strong decline in male employment has been partly compensated by increases in female employment. While labour market institutions and regulations remained breadwinner-biased for a long time, and remain so to some extent, provisions to support and accommodate female 
labour market participation developed alongside early on, making Belgium a case in point of what Knijn and Kremer (1997) have called 'optional famialism'. That is to say the caregiving mother is supported but at the same time families were given the option of at least partially outsourcing that care. Belgium has had extensive child care facilities for a longer time than its neighbouring countries, both in the form of institutionalized child care and through so-called substitute mothers. As a result, Belgium has consistently had among the highest percentages of young children in institutionalized care. At age 3 up to the mandatory school age, Belgium still ranks at the top in Europe, with a use of formal childcare arrangements of almost 100 per cent. Not surprisingly, maternal employment rates are also among the highest in the rich world, certainly among relatively highly educated mothers. Despite the availability of affordable child care employment rates among lower educated women remain very low probably reflecting a structural shortage of employment opportunities in Belgium's relatively atypical labour market.

Belgium maintains comparatively strong worker protection when it comes the conditions of work. The legal framework is comprehensive and deviations are only possible by collective agreement. Politics sets the framework within which flexibility is possible but as a general rule that can only be exercised by collective agreement, not through individual discretion on the part of individual employers or workers. Night time work, to take one example, is in principle not allowed in Belgium, except in cases where unions and employers reach a collective agreement that sets the terms and conditions. There are also relatively strong legal restrictions on temporary work contracts. It is not surprising therefore that there is not much evidence of increases in what some label precarious work. On several measures 'nonstandard' employment such as the incidence of fixed term contracts, temporary work, night work, weekend work, etc. Belgium is to be found at the lower end each time, usually below the EU15 average and certainly far below its northern European neighbours. In short, to the extent that there have been movements towards more flexibility in the sphere of contract type, working time and work organisation, these have been negotiated by the social partners rather than politically imposed. 


\section{Earnings trends}

Belgium is an international outlier in many respects but probably nowhere more so than in the sphere of earnings. As Table 2 shows, there has been steady real wage growth across the board, with labour maintaining a comparatively steady share in national income. In addition, Belgium maintains, by various measures and sources, just about the most compressed wage distribution in the capitalist world.

Figure 4: Real gross monthly earnings of full-time workers (normalized), Belgium 1999-2014

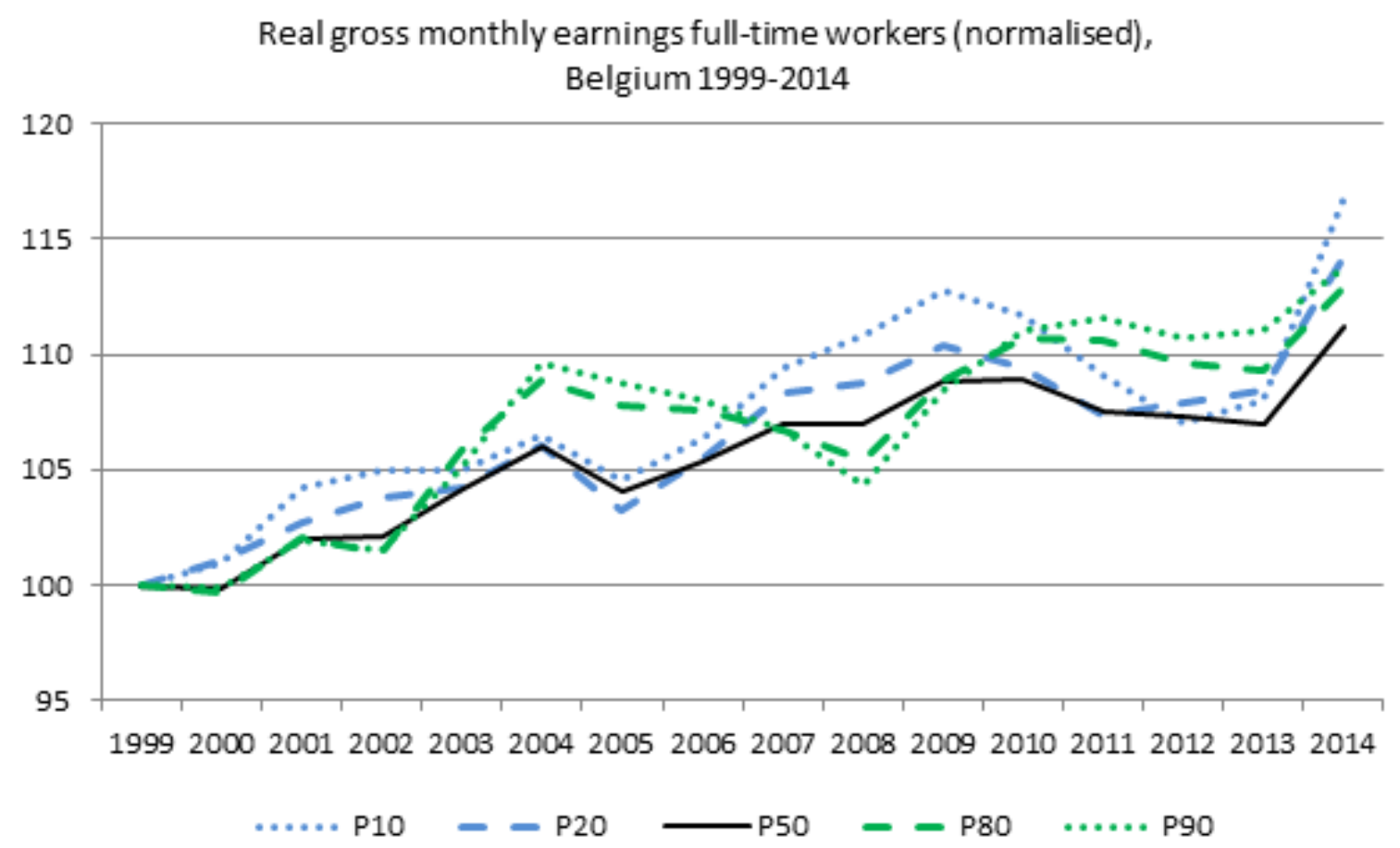

The figures in Table 2 are drawn from various sources, none of which allow for full correction of working hours trends. Yet we know that part-time work has increased, especially among women. The data sources on which we draw for Table 2 tend to capture earnings over the whole years and do not allow to account fully for work intensity during that year. Figure 4 shows trends in real monthly earnings of full-time workers as drawn from the OECD database, which is based for Belgium on the structure of earnings survey. It is more limited in time and it only captures full-time earners working in companies of a certain size. The figure shows substantial wage increases at all percentile cut-offs. The graph suggests that wage growth at the lower and higher end of the distribution was stronger than in the middle at times but the 
difference is not very large. This is broadly consistent with the patterns in Table 2 . The contrast with what happened in many other countries in this book is striking.

Various factors may account for Belgium's pattern of relatively equitable wage growth.

First, Belgium applies a so-called automatic indexation of wages to inflation so as to safeguard purchasing power. Concerns relating to wage cost competiveness have led consecutive governments to reform the relevant index, including a series of indexation freezes in the mid1980s and modifications of the basket of goods and services included. Wages and benefits are now adjusted through a variety of mechanisms to the so-called health index, a basket of goods that excludes unhealthy (e.g. cigarettes) and environmentally harmful items (e.g. petrol).

Second, wage setting is a matter in which unions and employers retain a significant degree of autonomy. Almost everybody's pay in Belgium is determined by a collective agreement. That is probably very important to Belgium's story. Many studies find a very strong link between the extent and strength of collective bargaining and wage outcomes, including growth and inequality (Bosch, 2015; Garnero et al, 2014; Plasman et al, 2007; Salverda and Checchi, 2014) Wage bargaining in Belgium occurs at three interlinked levels. A first round of bargaining at the national level results in an overall agreement, which covers all firms and sets out essential parameters, e.g. the scope for overall wage growth and minimum wage levels. Then a multitude of joint committees implement the national target at the sectoral level. A third round of bargaining can take place at the firm level, but this is not always the case (especially in smaller firms). Collective agreements are generally extended by the Ministry of Labour so as to cover just about the entire workforce.

This three stage bargaining model in combination with general extension and automatic costof-living adjustment mechanisms (indexation) has undoubtedly played an important role in the steady wage rises Belgian workers have enjoyed across the board.

Concerns about "competitiveness" have led consecutive governments to a more interventionist stance as to overall wage growth. The so-called 'Competitiveness Law' of 1996 (modified in 2014) institutionalized governmental intervention in wage setting when wage developments are considered harmful to competitiveness. A monitoring system benchmarks Belgian wage developments against those in main trading competitors and neighbouring countries Germany, France and the Netherlands. 
In addition to the fact that wages have continued to grow, there has been no increase in wage inequality, at least a far as the data shows. Belgium has just about the most compressed wage distribution among the rich countries, especially at the lower end of the distribution. The vast majority of workers are middle income workers. Apart from the way this feeds into overall middle class income standards, the fact that there been no growth in low-paid employment is striking fact in its own right. The contrast with Belgium's neighbouring countries is in fact quite striking. According to OECD figures for 2015, less than 4 per cent of Belgian workers work for relative low pay as the OECD defines it, against 9 per cent in France, 15 per cent in the Netherlands and 18 per cent in Germany.

Belgium does not have a statutory legal minimum wage. Instead there is a minimum wage on which employers and trade unions agree at the national level. It applies to all workers (collective wage agreements are legally binding, i.e. they also cover non-unionized workers) and it sets sector-wide or even national level thresholds and definitions of adequate pay. This minimum wage thus has more of a benchmark purpose than anything else - it constitutes the absolute base of the wage structure. "Real" minimum wages (i.e. pay scales for the youngest, least qualified and least experienced workers) are collectively negotiated the industry level and these tend to be considerably higher than the nation-wide minimum wage as they cannot undercut the national minimum standard. Industries where the lowest pay scales are 20 to 30 percent higher than the nation-wide minimum are not exceptional. In some sectors, the lowest pay scales are almost twice as high as the nation-wide minimum (Vandekerckhove \& Van Gyes, 2014; Marx et al., 2012). However, the minimum wage is reached at national level and the outcome of the negotiation there is reflective of overall union bargaining power (Vandekerckhove, Goos and Geys (2014). Thus higher effective minimum wages reduce not only lower-tail but also overall wage dispersion.

There is little or no specific information on top incomes but the earlier quoted OECD figures show stability of what they define as 'high pay' - the share of workers earning more than oneand-a-half time median earnings. It must be added however that because of Belgium's high personal taxation levels, people in traditionally high income professions (doctors, lawyers, high levels managers, etc) tend to channel much of their income to companies of which they are the sole shareholder. That is especially attractive since Belgium has no capital gains 
taxation, except in a limited number of specific cases. It is therefore quite plausible that household survey data underestimates top and even upper middle class incomes.

\section{$5 \quad$ Benefits and taxes}

While income from labour remains the principal income component of middle class households, certainly those at working age, benefits matter too. Belgium has one of the highest levels of public spending among OECD countries, with corresponding tax levels. Thus we now turn to the other major component of household disposable income, namely the public intervention in the form of taxes and benefits.

Very broadly speaking Belgium has a social security system in the Bismarckian mould. That is to say: benefits are gained through work and in principle proportional to previous wages and contribution records. The social partners play an important role in co-governing the system. Means-tested social assistance benefits and minimum pensions play a residual role and act as a final safety net. Unemployment benefits are an exceptionally large branch - compared to the EU28 average, Belgium spends twice as much on unemployment benefits. This is because apart from unemployment insurance proper, the unemployment insurance system also contains the principal early retirement scheme. Career interruption and worktime reduction benefits, which are among the most extensive in the OECD area, also fall within the system.

Belgium's fiscal system, sprawling and complex as it is, is not easily summarized but it is worth highlighting that personal income taxes play a large role in funding Belgium's high level of public spending, which at 53 per cent of GDP, stands among the highest levels found in the OECD area. Over recent years there have been tax shifts away from labour incomes towards taxing consumption and pollution, and to some extent capital income (mainly transaction taxes) but the bulk of government revenue still comes from personal taxation.

Drawing on Decoster et al. (2015) we can show the distributive impact of tax-benefit policies for two decades (1992-2012). The policies considered include social benefits (pensions, unemployment, social assistance and child benefits), social insurance contributions, personal income taxes and indirect taxes. Figure 5 shows the composition of disposable income over 
equivalent household disposable income quintiles ${ }^{6}$ for the tax-benefit policies in place in 2012 over the total population. The different components are expressed as a share of disposable income (amounts presented by the round circle in euro on the right axis). On average, market income is by far the major component. It is, however, only $45 \%$ of disposable income for the lowest quintile, as compared to $153 \%$ for the top quintile. Pensions and unemployment benefits make up $24 \%$ resp. $23 \%$ of disposable income in the lowest quintile. These shares decrease when households become richer. Child benefits are more important at the bottom $(11 \%)$ than at the top (2\%). Social assistance has some weight in the bottom quintile (4\%). The distributive pattern of the different taxes is as expected: personal income taxes are strongly progressive, social insurance contributions are slightly progressive, and indirect taxes are regressive.

Figure 5: Income source with respect to disposable income (\%), 2012 tax-benefit policies

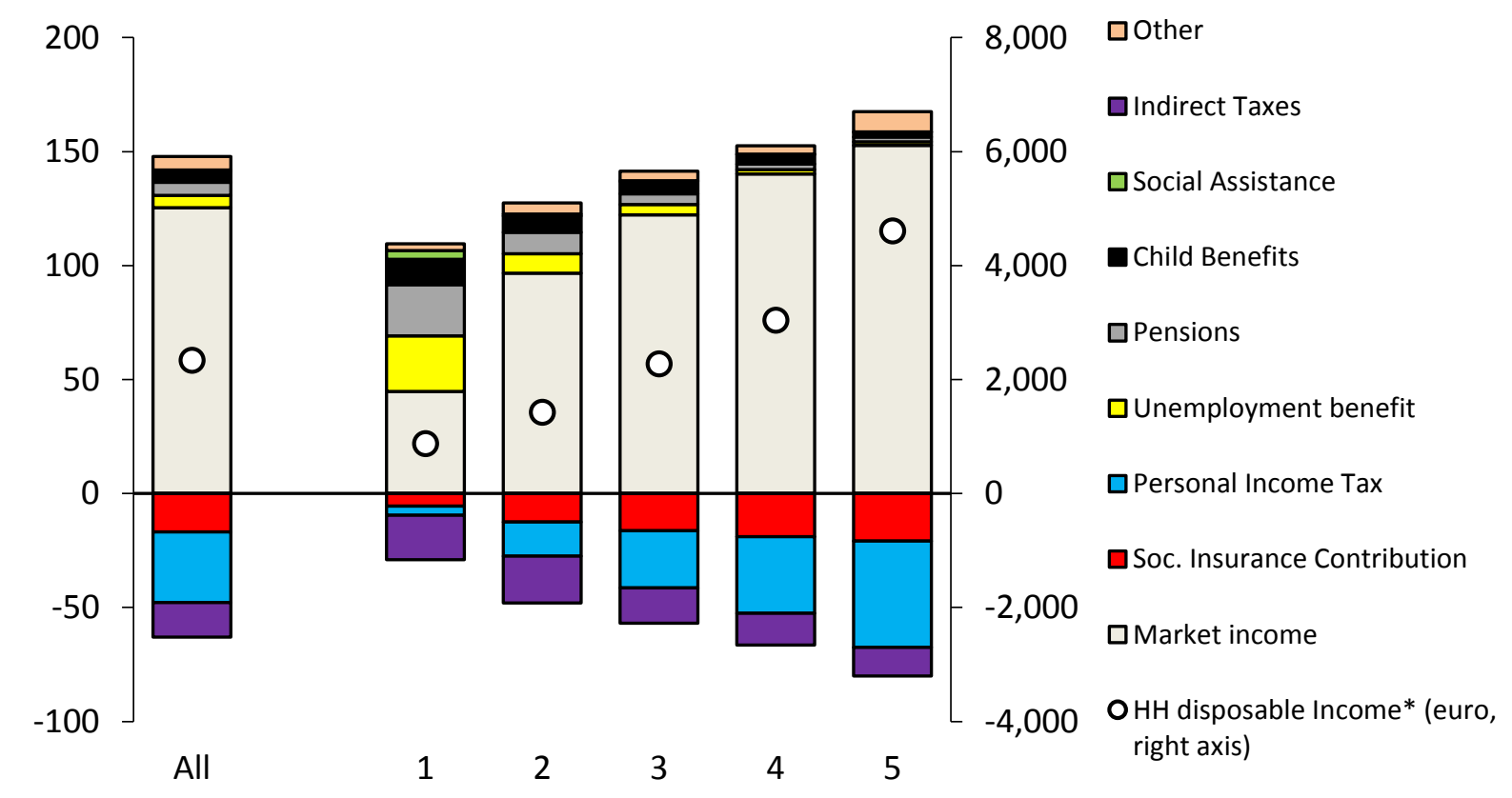

Source: Decoster et al., 2015; calculations based on 2010 SILC data.

\footnotetext{
${ }^{6}$ Quintiles are constructed on the basis of the counterfactual distribution in 1992, because in the next figures, where policy changes are described, quintiles to which individuals or households belong have been fixed. We chose for quintiles at the earliest point in time to interpret the changes across the distribution in the next paragraphs consistently.
} 
Figure 6 shows the difference in disposable income per quintile if the tax-benefit policies of 2012 were used as compared to those in 1992. A positive value indicates that the tax-benefit system has become more generous either in real terms (when price uprating is used as the uprating factor) or with respect to wage growth (using nominal wage growth as the uprating factor). The overall policy stance has been progressive, irrespective of the uprating assumption used. The uprating assumptions however, matter for the size of the effect. Figure 6 also provides more details for three different periods, notably (1) 1992-2001, which corresponds to an era of fiscal consolidation; (2) 2001-2007, as a period of economic uprise; and (3) 2007-2012, corresponding to the (post-)crisis period.

Panel (a), using price uprating as the benchmark, reveals for the period 1992-2001 the proportionate increase of social insurance contributions and personal income taxes, thus lowering disposable incomes (on average by $2.3 \%$, with lower decreases for lower incomes). Higher indirect taxes, most notably the increase of the VAT rate from $19.5 \%$ to $21 \%$, lowered household disposable income on average by another $0.6 \%$, in a way that was regressive. Social transfers remained by and large unchanged in real terms. Panel (b), using nominal wage growth as the benchmark, clearly shows the lack of welfare adjustments of pensions and unemployment benefits and, for the bottom quintile, additionally from the erosion of child benefits and minimum income protection. Also the upper part of the income distribution saw a decrease in real disposable income, following mainly from the non-indexation of the personal income tax brackets (bracket creep) during several years.

For period 2001-2007, Panel (a) shows that households' real disposable income increased by on average $4.4 \%$, mainly due to generous tax policies (the so-called Reynders reform). The increase was largest in the middle, but remained significant throughout the income distribution. The extension of the work bonus for low wages also increased incomes for the bottom two quintiles. During this period a number of welfare adaptations of social benefits, most notably of unemployment benefits, pensions and-to a lesser extent-social assistance took place. Reform of child benefits benefited the bottom quintile. The distributional picture is roughly similar for both the uprating scenarios, as real wage growth was relatively low in this period.

During and after the financial crisis the major driver of changes has been the welfare adaptations of pensions, and to a minor extent that of unemployment and social assistance 
benefits. In the period 2007-2012, the policy orientation was clearly progressive. As prices grew more than wages did in this period, the effects were amplified by using the wage uprating scenario.

In sum, during those twenty years policy makers have tended put 'equity first' (Decoster et al. 2015): in all three sub-periods (1992-2001; 2001-2007; 2007-2012), either when forced to make policy choices in an environment of fiscal consolidation or in a more favourable economic environment with substantial economic growth, increases in real disposable incomes were larger at the bottom of the distribution and decreases of disposable incomes were less pronounced at the bottom than further up the income distribution. This pro-poor stance, however, came at the cost of worsened work incentives (even despite the introduction of making-work-policies such as the work bonus). The analysis of Decoster et al. (2015) focuses on policy changes only, while Figure 2 and Tables 1 and 2 in this chapter show the evolution that includes both the impact of policy changes as that of changes in market incomes and socio-demographic changes (e.g. the shift to dual earnership; the ageing of the population; changes in household composition etc.). 
Figure 6: Changes in disposable income due to tax-benefit policy changes, Belgium 19922012 and three sub-periods

(a) Price Uprating

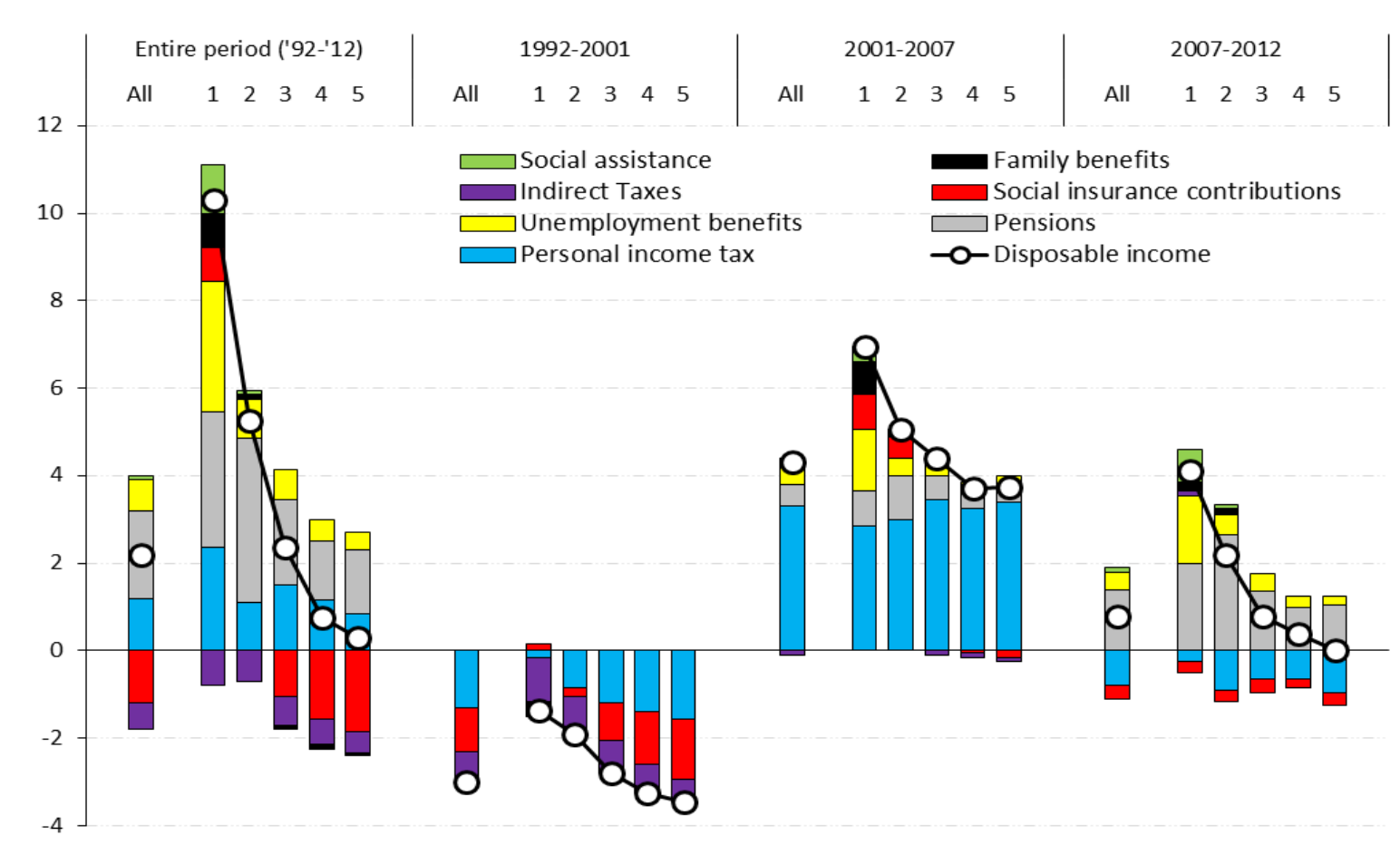

(b) Wage Uprating

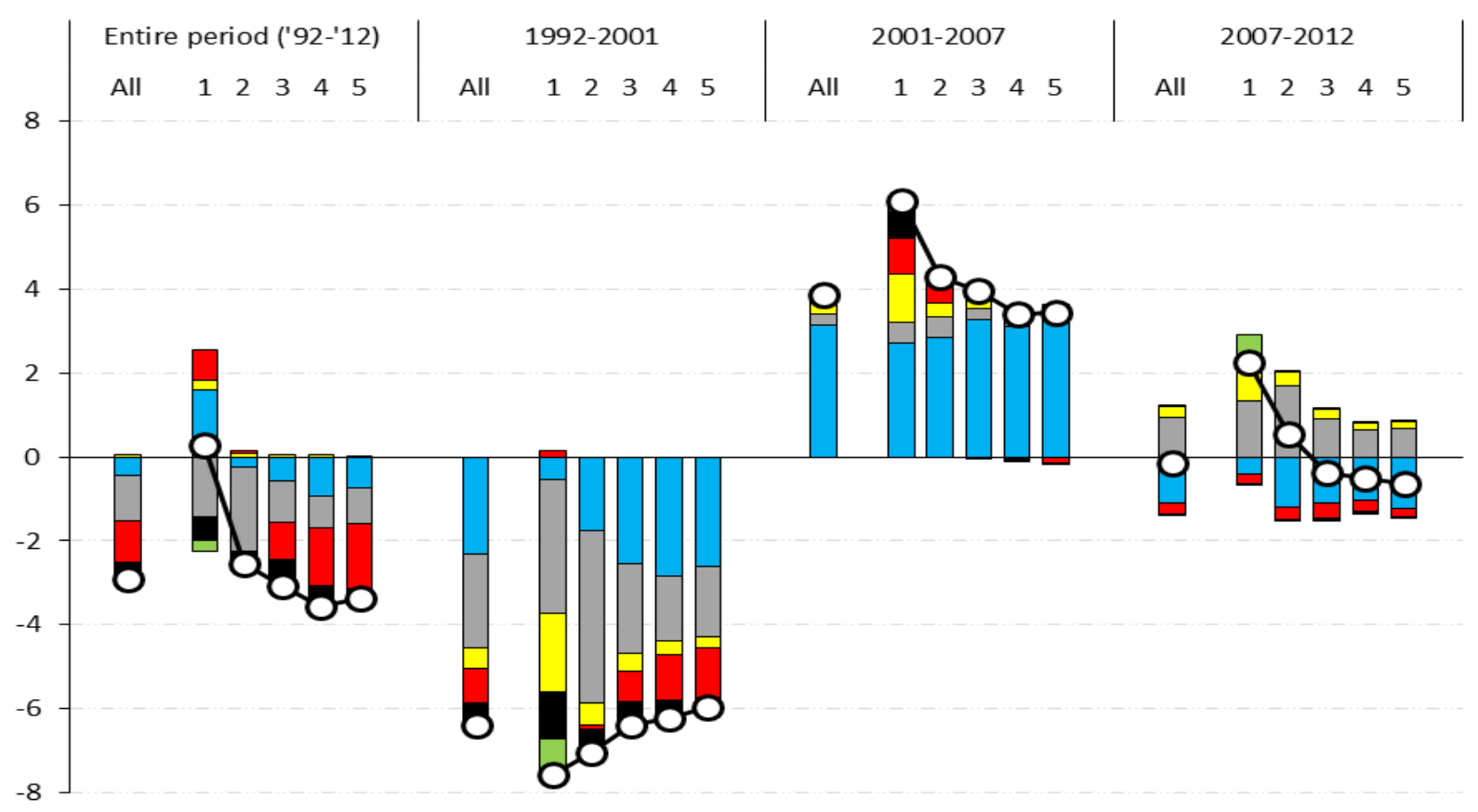

Source: based on Decoster et al. (2015); Calculations based on EU-SILC 2010 using MEFISTO-EM; quintiles of equivalent household income using 1992 tax-benefit system. 


\section{Education, housing and services}

So far we have only looked at taxes and benefits because these affect household incomes and living standard most directly. But the middle class also benefits from state provided or state subsidized services (Förster \& Verbist, 2011; Verbist and Matsaganis, 2014). This is certainly the case for such provisions as education, health or child care, all of which impose much higher burdens on middle class budgets in many other countries.

It is impossible to discuss these at length here but let us consider three examples of welfare state provisions of which middle class households are the main beneficiaries.

The first pertains to benefits and services related to having children. Child benefits are universal in that the same amount is given for each child, irrespective of income. Some categories of households get supplements but these are modest and certainly not anywhere near significant enough to make a noticeable difference to Belgium's relatively high child poverty rate. Thus middle and higher income households benefit fully from the system, as is reflected in Figure 4. Furthermore, childcare is heavily subsidized in Belgium and also widely available. The cost of subsidized child care is strongly earnings related so that low-income households pay much less than higher earning households. And yet, analysis shows that middle and higher income households are the main beneficiaries, as is also the case for parental leave and time credit schemes (Van Lancker and Ghysels, 2012). That is because the share of working parents is much higher among the relatively highly educated. While the subsidized child care system is designed to benefit the lowest income categories, labour market outcomes effectively counteract this policy intention creating a de facto Matthew effect. The same applies to education. Belgium has a very accessible educational system, with near free public education up until secondary level and relatively modest higher education fees compared with other OECD countries. Furthermore, financial assistance is available to lower income households. Yet again, analysis shows that the public resources that go into education, especially costly tertiary education, benefit the middle and higher socio-economic status households the most simply because children of relatively well-educated parents are still much more likely to enrol in tertiary education.

A second example is housing policy, where a clear middle class bias also exists. Belgium has a long-standing tradition in its so-called 'asset-based approach to welfare' (De Decker and 
Dewilde, 2010). Homeownership has been encouraged at least since the end of the nineteenth century. Already in 1889 the first housing legislation was implemented and over the years home acquisition was promoted by means of tax exemptions ('Woonbonus'), grants, premiums, social loans, social dwellings and social building parcels. Just under 7 out of 10 households own their home. Households in the (upper) middle of the income distribution benefit disproportionally from these policies to support home acquisition.

A third example is state subsidization of domestic services. Belgians can use so-called government issued "Service Vouchers" to pay for a range of domestic services like cleaning, washing and ironing. More than 70 per cent of the cost of these domestic services rendered to individual consumers is state subsidized. The scheme has proved tremendously popular, especially among highly educated dual earner households. Since these tend to be in the upper ranges of the income distribution the scheme amounts to a middle class perk of some magnitude (Marx and Vandelannoote, 2015). The main purpose of the scheme was to boost the employment chances of low-skilled women and also to reduce informal employment. Initially the scheme yielded some pay-off in that sense but as the scheme matured the effect weakened because more and more of the service voucher workers transitioned from other regular jobs to the scheme and fewer transitioned from unemployment or (formal) nonemployment (Raz-Yurevich and Marx, 2017). Employment rates among low-skilled women remain very low in Belgium.

\section{Is Belgium a poster child for inclusive growth?}

As this chapter and other recent studies show, Belgium's middle class has maintained its ground well, at least by income based measures of prosperity and well-being. That is not to say all is well.

To start with, middle class status eludes important sections of the population (Kuypers and Marx, 2016). Employment chances for those with less than secondary education are comparatively low (very low even) and continue to decline. Belgium has just about the highest share of working age people living in a household where nobody has a job. Such households generally do not enjoy anywhere near middle class living standards. In fact most live in 
poverty. The prospects of enjoying middle class living standards and lives for people with a migration background are downright dismal. Almost nowhere in the rich world is the nativemigrant socioeconomic achievement gap as big as in Belgium, be it in the sphere of comparative school outcomes, labour market outcomes, incomes and poverty (Pina et al, 2001; OECD, 2011b; OECD, 2012). Most damningly, perhaps, for a country with a comparatively low level of income inequality and a comparatively high level of social spending, Belgium has a remarkably high share of the population living in relative income poverty. Belgium's overall poverty rate, by the EU's relative at-risk-poverty threshold, has remained at around 15 per cent and child poverty close to 20 per cent. That is significantly higher than for example in the Netherlands, a country that has higher overall income inequality and a similar level of social protection spending.

The fact that Belgium is a mediocre performer when it comes to relative poverty may come as a surprise in the light of the intensified redistributive effects of taxes and benefits - which were already strong in the first place. But these have not managed to counteract other forces, particularly in the labour market, for example the declines in employment among the less skilled. As Cantillon has put it, the Belgian welfare state (as elsewhere) "has been working harder to stand still". Of course, the extent to which these labour market trends are to be seen as exogenous is a matter for debate. Relatively generous early exit schemes probably account in large part for the fact that so few Belgian work after the age of 50 . While early retirement is being scaled back inflows in sickness schemes appear to be inexorably on the rise. Belgium is still just about the only OECD country where there are no time limits on the receipt of unemployment insurance benefits, which is not to say that activation efforts have not intensified. Although exceptional, people have been known to retire after having lived on unemployment insurance for nearly all of their adult life. It is thus not implausible that at least some of the poverty standstill is due to endogenous effects of the welfare system itself. Similarly, Belgium's heavily regulated labour market, with strong restrictions on many forms of atypical employment is essentially self-imposed, as are the comparatively high minimum wage floors set by collective agreements. The extent of any causal link is uncertain of course, but the fact remains that employment rates for the low-skilled are among the lowest in the OECD area and benefit dependency rates among the highest. With so many people at working age dependent on benefits it will perhaps come as no surprise that benefit levels are often 
inadequate, especially after long periods of dependency, translating into very high poverty rates among those who have no other means of existence. The poverty rate among very low work intensity households, who are comparatively numerous, stands at around 60 per cent.

There is a rich literature on poverty and disadvantage in Belgium so we will not dwell on it further here. The focus of this chapter is on the middle class and so perhaps it is good to say something about aspects of the middle class experience that the trends reported here do not capture well or not at all.

Even when adjusted for price increases, it is plausible that a middle class income buys less than it used to of some items important to the way the middle classes experience their lives and living standards. Wages and living standards - defined as equivalized real disposable incomes- have held up well, but housing prices have gone up even more (Zwart, 2015). This is especially affecting the younger generation seeking affordable housing. In the aftermath of the crisis banks also have become more reluctant to provide housing loans. The younger aspiring middle class may find it considerably more difficult to realize a lifestyle similar to that of their parents in terms of space and living comfort.

Another missing dimension here is subjective well-being, particularly stress and work-life balance satisfaction. Dual earnership has become a prerequisite for a middle class living standard. This brings continuous work/care worries, especially, again, for younger people. The work/care conflict is especially acute in the Belgian context because work is so unevenly spread over the life cycle. Belgians enter the labour market relatively late yet at the same time the effective age of retirement in Belgium remains among the lowest in the OECD. Reemployment chances for workers over 50 are very low. This imposes extremely strong pressures to perform and work hard at prime-age, with stress levels to match.

A third aspect that conventional measures of middle class well-being do not capture well is perceived insecurity. Belgium has gone through a period of massive deindustrialization resulting in equally massive job losses. This trend has waned but Belgium remains exposed to strong international competition and to technological change. Mass lay-offs remain daily fare in the news media. It is becoming apparent that the jobs most strongly affected by technological change are not those at the very bottom of the earnings and skills distribution but the jobs in the middle (Goos, 2099; 2013). Archetypal middle class jobs like bank clerks are 
one example. Several banks in Belgium have over the past years announced lay-offs, mostly of workers in these types of jobs. Up until recently relatively generous early retirement schemes provided a comfortable exit from the labour market. But early exit routes are being narrowed because of cost concerns. The mechanisms that secured and sustained middle class living standards even when middle class jobs were disappearing are themselves under threat. Consecutive governments have tried to close down early exit routes. The current government has again increased the age requirements for the main early retirement scheme. Yet we should not overstate the extent to which state generosity vis-à-vis the middle class is being cut back. While some early exit routes are being tightened, caseloads in other schemes are rising fast, notably in sickness and disability. While a clear case can be made for more forceful action in stemming this new surge in benefit dependency, the political mechanisms of the past re-emerge, be it in weakened form.

\section{Prospects}

Belgium's middle classes closely guard and defend what they consider to be their legitimate and 'acquired' rights, including high wages that are automatically adjusted for price rises, high job security, limits on work time flexibility and welfare state and tax perks of all kinds. The middle class retains formidable power to voice protests - through unions and affiliated organisations - and to punch more than its weight in Belgium's highly competitive landscape. The middle income voter remains the key battle ground at the federal, regional and local level, all of which have proportional electoral systems. Parties that succeed best in capturing the middle segment of the electorate tend to hold the key to cabinet formation in a political system that requires coalition building and where a strong centre party almost by definition holds the key to power. In that sense it would appear that Belgium's middle class has little to fear, at least in the immediate future.

However, it is not so certain the policies that politicians currently put forward in pursuit of middle class approval every election also serve its longer term interests. Government spending as a percentage of GDP is already among the highest in the world, much of it resulting from politicians seeking to please their middle class electorates at Belgium's many 
levels of government. In addition, and for much of the same reason, Belgium is facing a considerable public debt mountain. This would perhaps not be highly problematic were it not for the large unfunded pension liabilities on the horizon. With taxes already at levels that are among the highest in the rich world there may not be much scope for significant further increases there. The OECD is forecasting that without consolidation and pension reform the public debt will increase to what it deems to be unsustainable levels (OECD, 2015). Yet politicians remain hesitant to curb expenditures on even the most blatantly (higher) middle class oriented expenditures.

However, Belgium is still very far from fiscal collapse. Belgian households hold assets that far exceed Belgium's public debt, which stands at 100 per cent of GDP. Financial assets held in Belgian bank accounts alone exceed that debt by a factor of two. According to HFCS data, median net household wealth is the highest in the Eurozone after Luxembourg and Cyprus. That wealth appears to be more equally distributed than elsewhere - Belgium's Gini coefficient for wealth is among the lowest in the rich world. Analyses of the joint distribution of income and wealth show that much of it is held by what have labelled here middle income households (Kuypers and Marx, 2016). In addition, Belgium's economy keeps developing at a steady pace; the country maintains a large trade surplus and foreign direct investment remains quite substantial (be it some of it capital in transit various because of fiscal measures to attract it).

Finally, it worth highlighting again that Belgium has proven itself to be more adaptive than it often appears from the outside. It has no tradition of big policy changes, creating the impression of sclerosis from afar. Decades of linguistic conflict have yielded a complex, multilayered system of governance with intricate power balances in which drastic change is almost impossible to achieve. Yet change happens, in ways barely noticeable to outsiders, often through seemingly administrative-technical alterations that incrementally accumulate into bigger shifts (see for example Anderson et al, 2007; De Deken, 2011).

Belgium will probably continue to muddle through in its own inconspicuously, mildly successful way. An attractive model for inclusive growth for the rest of the world to emulate it does not offer perhaps. Belgians themselves, meanwhile, seem to be as concerned about that as Liberace was about critical acclaim. 


\section{Bibliography}

Anderson, K. M., Kuipers, S., Schulze, I. \& van den Nouland, W. (2007). Belgium: Linguistic veto players and pension reform. In E. M. Immergut, K. M. Anderson \& I. Schulze (Eds.), The Handbook of West European Pension Politics (pp. 297-346). Oxford: Oxford University Press

Bosch, G. (2015). Shrinking collective bargaining coverage, increasing income inequality: A comparison of five EU countries. International Labour Review, 154(1), 57-66.

De Decker, P., \& Dewilde, C. (2010). Home-ownership and asset-based welfare: the case of Belgium. Journal of Housing and the Built Environment, 25(2), 243-262

De Deken, J.J. 2011. "Belgium: A Precursor Muddling Through?." In Regulating the Risk of Unemployment, ed. J. Clasen, and D. Clegg. Oxford: Oxford University Press, 100-120.

Decoster, A., Perelman, S., Vandelannoote, D., Van Heukelom T. \& Verbist, G. (2015), 'Prélèvements fiscaux et prestations sociales en Belgique : l'impact de vingt années de réformes', Revue Française d'économie, vol.29(4), pp.84-127.

Dolls, M., Fuest, C. \& Peichl, A. (2012). Automatic Stabilizers and Economic Crisis: US vs. Europe. Journal of Public Economics, 2012(96), 279-294.

Förster, M. \& Verbist G. (2011), 'The Distributive Impact of Publicly Provided Services', in OECD (2011), Divided We Stand. Why Inequality Keeps Rising, OECD Publishing, Paris, pp.309-341.

Garnero, A., Kampelmann, S., \& Rycx, F. (2014). Minimum wage systems and earnings inequalities: does institutional diversity matter? European Journal of Industrial Relations, 116.

Goos, M. (2013). How the world of work is changing: a review of the evidence. Geneva: International Labour Organization.

Goos, M., Manning, A., \& Salomons, A. (2009). Job polarization in Europe. American Economic Review Papers and Proceedings, 99(2), 58-63.

Hemerijck, A. \& Marx, I. (2010). Continental Welfare at a Crossroads: The Choice between Activation and Minimum Income Protection in Belgium and the Netherlands. In B. Palier (Ed.), A long goodbye to Bismarck? The politics of welfare reforms in continental Europe (pp. 129155). Amsterdam: Amsterdam University Press.

Hijzen, A. \& Venn, D. (2011). The Role of Short-Time Work Schemes during the 2008-09 Recession, Employment and Migration Working Papers, 115. OECD Publishing.

Horemans, J., O. Pintelon, et al. (2011). Inkomens en inkomensverdeling op basis van Belgische enquêtegegevens: 1985-2007. Antwerpen, UA/Centrum voor Sociaal Beleid Herman Deleeck.

Knijn, T. and M. Kremer (1997), "Gender and the Caring Dimension of Welfare States: Toward Inclusive Citizenship", Social Politics: International Studies in Gender, State \& Society, Volume 4, Issue 3, 1 October 1997, Pages 328-361, 
Lanchester, J. (2011). "The Non-Scenic Route to the Place We're Going Anyway." London Review of Books 33(17), 3-5.

Marx, I. (2009). Belgium: a post-Bismarckian welfare state looking for legitimacy, sustainability and a way out of 'welfare without work'. In Schubert et al. (eds.), European Welfare Systems. New York: Routledge.

Marx, I. \& Kuypers, S. (2015). Social concertation and middle class stability in Belgium. In D. Vaughan-Whitehead (Eds.), Europe's disappearing middle class? Evidence from the world of work. Genève: International Labour Organisation.

Marx, I., \& Vandelannoote, D. (2015). Matthew runs amok: The Belgian service voucher scheme. In C. Carbonnier, \& N. Morel, The political economy of household services in Europe. Basing-stoke, UK: Palgrave-Macmillan.

Nolan, B., Salverda, W., Checchi, D. Marx, I. McKnight, A. Tóth, I. Werfhorst, H. (eds.) Changing inequalities and societal impacts in rich countries : thirty countries' experiences, Oxford University Press, 2014-743 p.

OECD. (2004). Employment Outlook 2004: Wage-setting Institutions and Outcomes. Paris: OECD Publishing.

OECD (2008). Growing Unequal: Income Distribution and Poverty in OECD Countries. Paris: OECD.

OECD. (2011). Divided We Stand: Why Inequality Keeps Rising. OECD. Paris: OECD Publishing. OECD. (2011b). PISA in Focus 2011. How are schools adapting to increasing numbers of immigrant students? Paris: OECD Publishing.

OECD. (2012). Settling In: OECD indicators of immigrant integration 2012. Paris: OECD Publishing.

OECD. (2013). Employment Outlook 2013: Protecting jobs, enhancing flexibility: A new look at employment protection legislation in OECD. Paris: OECD Publishing.

OECD. (2015). Economic Survey of Belgium. Paris: OECD Publishing.

OECD (2015), In It Together: Why Less Inequality Benefits All Paris: OECD Publishing.

Pina, Á., Corluy, V., \& Verbist, G. (2015). Improving the labour market integration of immigrants in Belgium. OECD Economics Department Working Papers No. 1195.

Plasman, R., M. Rusinek, et al. (2007). Wages and the Bargaining Regime under Multi-level Bargaining: Belgium, Denmark and Spain. European Journal of Industrial Relations, 13(2), 161180.

Raz-Yurevitch, L. and I. Marx (2017), "What Does State-Subsidized Outsourcing of Domestic Work do for Women's Employment? The Belgian Service Voucher Scheme", in Journal of European Social Policy 
Salverda, W. \& Checchi, D. (2014). Labour-market institutions and the dispersion of wage earnings. IZA: discussion paper series, 8220.

Vandekerckhove, S. \& Van Gyes, G. (2012). Collective agreed wages in Belgium: indicators and trends. Leuven: HIVA -Research Institute for Work and Society.

Vandekerckhove, S. \& Van Gyes, G. (2014). Minimum wages in Belgium: a maze, or amazing? Brussels: European Commission.

Vandekerckhove, S., Goos, M., \& Van Gyes, G. (2014). Reassessing the impact of minimum wages on wage dispersion and employment: evidence from an institutionalized wage bargaining system. PEAC Conference Brussels.

Van Lancker, W., \& Ghysels, J. (2012). Who benefits? The social distribution of subsidized childcare in Sweden and Flanders. Acta Sociologica, 55(2), 125-142.

Van Rie, T \& Marx, I. "Belgium : when growing background inequalities meet resilient institutions", in Changing inequalities and societal impacts in rich countries : thirty countries' experiences / Nolan, Brian [edit.]; Oxford University Press, 2014-p.126-151

Verbist, G. \& Matsaganis, M. (2014) 'The Redistributive Capacity of Services in the European Union' in Bea Cantillon and Frank Vandenbroucke (eds.), Reconciling Work and Poverty Reduction. How Successful are European Welfare States?, Oxford, Oxford University Press, pp.185-211

Zwart, S. (2015), Maintaining an Efficient and Equitable Housing Market in Belgium OECD Economics Department Working Papers 1208 